certain communicable diseases: diphtheria antitoxin, serum for the treatment of cerebrospinal meningitis, typhoid vaceine, smallpox vaccine. All these things are free to any reputable practising physician.

What does the State ask in return for theso things which she furnishes to her citizens free? In the first place, she asks that the physicians report promptly all cases of communicable diseases, births and deaths within their knowledge. She asks these things, but she does not always get them. Physicians are often very careless about reporting births, sore eyes in babies, and communicable diseases in older children or adults, yet the health authorities of both town and State are powerless to control disease, the existence of which they are unable to ascertain. 'They are powerless to estimate the infant mortality if they do not know how many babies are born. They camnot tell whether or no an epidemic is threatening from a given milk supply if the practising physician in charge of each individual case of disease is careless about reporting the milk supply of each of his cases of communicable diseases. I recently looked over 120 reports from physicians in one eity, and from that number only 26 gave the name of the milkman supplying milk to the infected families, although the space for such a report was clearly indicated on the card.

Tuberculosis is a poorly reported disease, although it is of the utmost importance. Physicians, seeing a case of the latter disease, frequently take it for granted that it has been already reported because it has been seen previously by some other physician. The law does not contemplate taking anything for granted. Better that a case be reported four times than that it be not reported at all. The State Department of Health has a system whereby cases reported more than once are not counted more than once, so that multiple reports do not vitiate our statistics.

Finally, the State has a right to ask that the physicians be the first to support all matters which tend to promote the health and happiness of the eitizens of the Commonwealth. How can this best be done? The physician should be the adviser of his families, not merely in times of sickness, but in times of health. $\mathrm{He}$ should give more thought to the prevention of ailments, while not relaxing in any way his endeavors towards cure when ailments do appear. This may sound Utopian, but as a matter of fact it is not so. We all know in what a state of flux the public mind is at present in medical matters. Many people are becoming distrustful of the old measures of treatment, and they are taking more interest in prophylaxis. They read in the newspapers articles on the cause and prevention of disease-information they too often do not get from their family physician. The old type of family practitioner is said to be gradually disappearing, and it is greatly the fault of the medical profession itself. On the other hand, I listened not long ago to a paper by a Boston physician in which he described an experiment which he has been carrying on for a year with some fifty families. They consider him their family physician, and call him when they get sick, but he feels disappointed if they have to call him often for that reason. His great work lies in the direction of prevention. IIe makes careful examination of his patients while they are well, visits them while they are well, and does his best to keep them well. I feel strongly that this is the inevitable outcome of the changes taking place at the present time. Only in this way will the physician be able to cope with conditions arising from the newer forms of social thought, such as health insurance, for example.

'To sum up the gist of our subject, the family physician should be the strongest ally which the hoard of health has. He should work hand in hand with the board, should see that the best representatives of the profession get on the board of health, and that they get adequate compensation for this work. He should work for the appointment of trained; full-time health officers in the cities and towns; he should work for the employment of public health nurses; for an adequate water supply, sewer system, and milk inspection. He should realize that his greatest function is to be the adviser of his families in all things which pertain to their physical and mental welfare. He should learn to think in terms of community as well as in terms of family.

\section{OIIniral Alepartment.}

\section{REPORT OF A CASE OF CONGENITAL ANOMALY OF THE LARYNX.*}

\author{
By Grorge H. Powers, M.D., Boston.
}

Stenoses of the larynx and upper trachea from congenital anomalies are quite rarely seen, although of frequent occurrence as a result of contracting cicatrices following destructive inflammatory processes commonly seen in diphtheria, syphilis and tuberculosis. The congenital stenosis is usually found to be a web of fibrous tissue situated between and adherent to the vocal cords, such opening as is present being at the posterior commissure. Diagnosis by means of the laryngoscopic mirror is, under ordinary.conditions, a simple matter, but if impraeticable, as in an infant, direct examination under anesthesia should be conclusive. The literature upon this subject, beyond the fact that there are found in this region anomalous membranous diaphragms, is rather scanty. Treatment consists in two methods, operative and by slow dilatation. Of the former, two routes are open,- the intralaryngeal atteinpt to cut away the obstruction 
following with dilatation, and externally opening the larynx in the median line for the complete removal of the superfluous tissue. 'The latter method is a last resort on account of the probable permanent impairment of the voice. A great variety of dilating instruments has been described, both for intra-laryngeal use from above and for intra-tracheal use from below through a tracheal opening. Several forms of the latter are constructed for attachment to the tracheotomy tube, the dilator projecting upward through the trachea and even through the larynx, according to the site of the lesion. 'The case here reported presented some very peculiar, and to me, unusual, features :

Immediately after birth the infant had no apparent respiratory difficulty, although a peculiar inspiratory sound similar to the cooing of a dove, was noticed. Labored breathing was not observed until some twelve hours later. 1)r. Richard M. Smith was called in consultation on the next day, and after a thorough examination a persistent thymus was most seriously considered. $\Lambda$ subsequent roentgen examination of the chest was negative in this respect.

On Tuesday, June 27 , when the infant was about 36 hours old, the respiratory difficulty became very alarming; the breathing became progressively more labored, and the respirations more shallow, until the baby was utterly exhausted and cyanotic. Through out the previous 24 hours, during periods of crying, respirations were much deeper and the cooing sound much more pronounced. $\Lambda t$ the time of the writer's first examination the baby's physical condition seemed desperate; the pulse was racing at 180 , at times being almost uncountable; respirations were shallow, labored, and from 60 to 80 per minute; marked cyanosis was present. Any laryngenl examination or procedure was considered out of the question, and tracheotomy under slight ether anesthesin was at once done. Unfamiliarity with the soft trachea, as yet practically without cartilaginous development, of an infant but little over 36 hours old, added considerable difficulty to this simple operation, the trachea being so soft that great difficulty was found in holding it with sufficient firmness to permit of an incision. Immediately upon insertion of the tube, however, the breathing became decper and the cyanosis gradually lessened. For the succeeding four days respirations were at times very irregular, varying from 40 and upwards to Cheyne-Stokes; this may have been due in part to exhaustion and insufficient oxygen. No further attempt at diagnosis was considered practicable until such time as the patient's condition would permit of surgical procedure. The subsequent tracheotomy history of the baby was uneventful, as evidenced by the weight table.

After a weekly gain for several weeks of 6-7 ounces, on Oet. 10 the baby, then some $31 / 2$ months old, was etherized and the larynx inspected by direct examination, but with some difficulty on account of a great quantity of mucus and a very soft, flabby epiglottis. No abmormality was found above the vocal cords, which were normal in appearance, closure and excursion; but below the glottis no tracheal lumen was seen, there being visible just below the cords what appeared to be a flat diaphragm of normal mucosa corresponding in color with the false cords. $\Lambda$ long pair of round-pointed nasal dressing forceps was now introduced through the larynx, pressing gently into this membrane, and gradually opened in line with the slit of the glottis to about 1/3 inch and the process repeated at a right angle. Considerable bleeding interfered seriously with further examination, but great improvement in breathing was noticed, which obtained for 20 minutes before the tracheal tube was replaced, during which time the wound was kept closed. Respiration now appeared normal, except for the presence of mucus and blood in the trachea and larynx, which faot was taken as definite proof that the obstruction eonsisted solely in this thin membranous diaphragm.

The tracheotomy tube was now replaced, and it was decided, if possible, to introduce, at the occasions of removal of the tube for cleansing, a pair of thin eurved forcens upwards through the tracheal opening to the site of the obstruction, for the purpose of stretehing the membrame as before. This was done at intervals of 2-3 days, by Dr. Charles $\mathrm{O}$. Day, the family physician, for nearly three weeks, each dilatation causing a slight bleeding, but no more apparent discomfort to the patient than removal and replacement of the tube. During the absence of the tube on these occasions, grcat improvement in breathing through the normal channel was noticed. $\Lambda$ fter the last dilatation on Oct. 29, the tracheal tube was not replaced for a half hour, during which time the little patient appeared quite happy, breathing deeply and with perfect freedom. Two days later the tube was permanently omitted, and a dressing applied over the tracheotomy wound. Respiration was apparently perfectly sufficient and normal, excepting the slight sounds caused by mucus in the trachen, to control which minute doses of atropine for about a week's time were necessary.

During this last visit the webbing together of the second and third toes of both feet was brought to my attention. This had so far escaped notice, and the discovery brought out the fact that this condition has been more or less common in the maternal family tree. The incident of the webbed toes was very interesting, for at the time of the tracheotomy. upon being pressed for a possible explanation of the obstruction, my guess was a web across the larynx or trachea, which $I$ likened to the not uncommon condition of webbed toes. My remark, however, at this time of excitement, brought forth no recollection of this family trait.

\section{ffltè̀tral fragregr.}

\section{TWELFTH REPORT OF PROGRESS IN ORTHOPAEDIC SURGERY.}

By M. S. DANFokth, M.D., Ronert Soutten, M.D., C. H. Buciorz, M.D., H. C. Isow, M.D.,

R. B. Osgood, M.D., Boston.

\section{TUBERCULOSIS.}

WHitBeck, ${ }^{1}$ in reporting the work for ten years at the Sea Breeze Hospital, calls attention to the fact that this is practically the only institution in America where the treatment of surgical tuberculosis can be continuously carried out for any length of time. Since 1904, 262 